\title{
APLIKASI TRANSPARANSI DANA DONASI UNTUK ANAK YATIM PIATU BERBASIS WEB
}

\author{
${ }^{1}$ Imas Maslekha, ${ }^{2}$ Riyanto Mustolih, ${ }^{3}$ Dedih, \\ imas@gmail.com, riyanto@gmail.com,dedihthea@gmail.com
}

\begin{abstract}
Abstraksi
Yayasan yatim piatu mendapatkan dana operasional dari para donatur. Namun bentuk pengeluaran dana bantuan belum dikelola secara transparan dan dilaporkan kepada seluruh donatur. Untuk itu diperlukan suatu aplikasi transparasi dana donasi anak yatim piatu yang berbasis online sehingga memudahkan pihak yayasan dalam mempertanggungjawabkan kegiatan dana donasi dan para donatur dapat dengan mudah mengakses laporan ketika dibutuhkan.

Kata kunci : Aplikasi transparansi,dana donasi
\end{abstract}

Abstract

Orphanages get operational funds from donors. However, the form of aid expenditure has not been managed transparently and reported to all donors. For that we need an application transparasi donation fund orphans based online so as to facilitate the Foundation in accounting for the activities of donation funds and donors can easily access the report when needed

Keywords: Application of transparency, donation fund 


\section{PENDAHULUAN}

Kegunaan sistem informasi bagi organisasi dapat membantu mempermudah suatu pekerjaan dan dalam pengambilan suatu keputusan dengan cepat dan efektif dengan tidak mengurangi kualitas (Welim dan Anugerah, 2016). Pemanfaatan teknologi informasi untuk yayasan sosial dapat membentuk sistem informasi berbasis web (Fitriana, dan Ridho, 2014). Pengenalan mengenai panti asuhan kepada masyarakat dapat dilakukan dengan kemampuan teknologi internet (Supriyanta dan Eunike, 2016)

Panti asuhan/lembaga asuhan merupakan tempat anak untuk menerima pengasuhan sementara ketika keluarga tidak rnampu memberikan pelayanan pengasuhan yang mencukupi bagi anak. Transparasi pengelolaan dana sumbangan penting guna menghindari terjadinya penyelewengan dana publik dan menghindari aspek hukum atas penggelapan dana masyarakat. Yayasan yatim piatu Nahdlatul Ishlahiyah merupakan salah satu lembaga pelayanan sosial semi panti yang ada di kabupaten Karawang. Saat ini yayasan yatim piatu Nahdlatul Ishlahiyah sudah menampung anak yatim piatu sekitar 34 anak dari berbagai latar belakang yang berbeda, yang terdiri dari santri ikhwan dan akhwat yang masih berstatus pelajar mulai dari kelas 3 Sekolah Dasar (SD), Sekolah Menengah Pertama (SMP) dan Sekolah Menengah Atas (SMA). Untuk memenuhi kebutuhan sehari-hari, yayasan yatim piatu Nahdlatul Ishlahiyah mengandalkan sumber dana dari donatur. Selama ini di yayasan yatim piatu Nahdlatul Ishlahiyah proses pengelolaan dana donasi masih secara konvensional dan belum terkomputerisasi. Sehingga sering terjadi human error seperti kesalahan dalam pencatatan pengeluaran donasi yang menyebabkan data menjadi tidak akurat dan tidak relevan.

Yayasan yatim piatu Nahdlatul Ishlahiyah tidak melakukan transparansi dana donasi dan pelaporan penggunaan dana donasi diberikan hanya kepada donatur yang membutuhkannya. Informasi mengenai penggunaan dana donasi tidak diketahui oleh seluruh donatur yang sudah terdaftar sebagai donatur tetap di yayasan yatim piatu Nahdlatul Ishlahiyah. Adapun solusi yang dibuat adalah membangun aplikasi yang memanfaatkan teknologi internet yang saat ini banyak digunakan dan mudah diakses oleh siapapun. Sehingga seluruh donatur dapat melihat data pemasukkan dan pengeluaran yayasan. Pelaporan dana donasi dapat disampaikan secara transparan. Membangun aplikasi ini menggunakan metode System Development Life Cycle (SDLC) model waterfall dengan pendekatan berorientasi objek. Siklus hidup pengembangan sistem adalah metodelogi untuk merancang, membangun dan memelihara informasi (Satzinger dk, 2010).

\section{TINJAUAN PUSTAKA}

Menurut Harahap (2012), "perangkat lunak aplikasi adalah suatu subkelas perangkat lunak komputer yang memanfaatkan kemampuan komputer langsung untuk melakukan suatu tugas yang diinginkan pengguna. Biasanya dibandingkan dengan perangkat lunak sistem yang mengintegrasikan berbagai kemampuan komputer, tapi tidak secara langsung menerapkan kemampuan tersebut untuk mengerjakan suatu tugas yang menguntungkan pengguna".

Menurut Kamus Besar Bahasa Indonesia (2016), "transparansi berasal dari kata transparan yang memiliki arti tembus cahaya; keadaan nyata, jelas, jernih; barang (plastik dan sebagainya) yang tembus cahaya yang dipakai untuk menayangkan tulisan (gambar) pada layar proyektor".

Menurut Dewantry (2015), "Donasi adalah suatu pemberian yang mempunyai sifat sukarela dengan tanpa adanya imbalan bersifat keuntungan, walaupun pemberian donasi dapat berupa makanan, barang, pakaian, mainan ataupun kendaraan akan tetapi tidak selalu demikian, pada peristiwa darurat bencana atau dalam keadaan tertentu lain".

Menurut Kamus Besar Bahasa Indonesia (2016), "yatim piatu adalah sudah tidak berayah dan beribu lagi. Jadi, anak yatim piatu adalah seorang anak yang sudah tidak memiliki ayah dan ibu karena kedua orang tuanya sudah meninggal". 


\section{METODE PENELITIAN}

\section{Bahan penelitian}

Bahan penelitian di dapat dengan melakukan wawancara pada pihak pengurus Yayasan dan melakukan studi literatur dari jurnal, buku dan ebook mengenali teori SDLC.

\section{SDLC waterfall}

Metode pengembangan sistem yang dipakai yaitu SDLC waterfall menurut Satzinger SDLC waterfall yang terdiri dari project planning phase, analysis phase, design phase, implementation phase dan support phase yang diperlihatkan pada gambar dibawah ini :

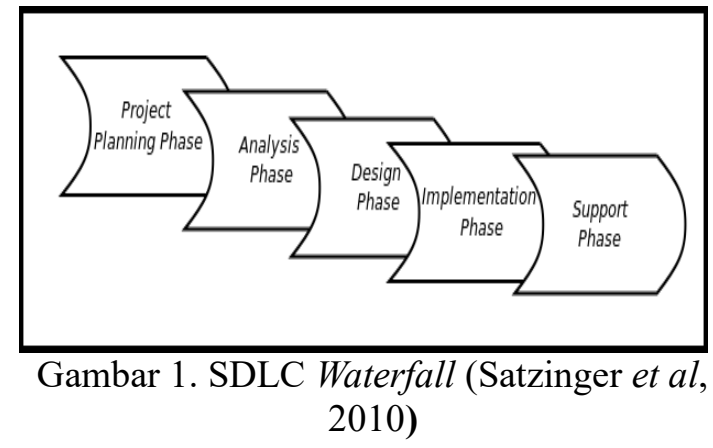

\section{Project Planning Phase}

Pada tahapan ini melakukan teknik dengan cara mengidentifikasi masalah yaitu diperlukan untuk membangun suatu aplikasi berbasis web yang terhubung oleh internet dapat membantu dalam menyampaikan informasi mengenai pelaporan dana donasi kepada seluruh donatur yayasan yatim piatu Nahdlatul Ishlahiyah dengan menerapkan metode SDLC Waterfall, pembuatan jadwal, kelayakan proyek dari segi ekonomi, sumber daya, teknik dan teknologi seta pembuatan tim proyek.

\section{Analysis Phase}

Untuk bagian ini dimulai dari pengumpulan informasi tentang yayasan, prosedur berjalan dalam penerimaan dana donasi, menentukan kebutuhan hardware dan software, membuat System activities (deskripsi use case, aktor, skenario, dan use case diagram), class diagram, sequence diagram dan activity diagram.

\section{Design Phase}

Sesudah analysis phase dilakukan selanjutnya tahapan desain dapat dimulai. Pada proses ini terdiri dari desain proses dan desain antarmuka.

\section{Implementation Phase}

Kegiatan implementasi membangun konstruksi program (instalasi program), pelatihan prosedural yang dilanjutkan dengan pengujian sistem (pengujian white box dan black $b o x)$ yang akan dijalankan pada lingkungan.

\section{Support Phase}

Pada fase pendukung ini, dilakukan pemeliharaan sistem agar sistem yang telah di terapkan dapat berjalan secara maksimal.

\section{HASIL DAN PEMBAHASAN}

\section{Hasil Project Planning Phase}

Pada project planning phase dihasilkan rincian setiap aktivitas yang dilakukan adalah sebagai berikut :

Tabel 1. Hasil Project Planning Phase

No Tahapan Hasil

1. Identifikasi 1. Dengan membangun suatu Masalah aplikasi berbasis web yang terhubung oleh internet dapat membantu dalam menyampaikan informasi mengenai pelaporan dana donasi kepada seluruh donatur yayasan yatim piatu Nahdlatul Ishlahiyah.

2. Dengan menerapkan metode SDLC Waterfall

2. Pembuatan Target membangun aplikasi jadwal ini dimulai dari bulan Oktober 2017-Januari 2018

3. Konfirmasi Dilihat dari segi manfaat Kelayakan aplikasi lebih besar dari pada Proyek biaya yang dikeluarkan. 1. Aspek Sumber Daya 


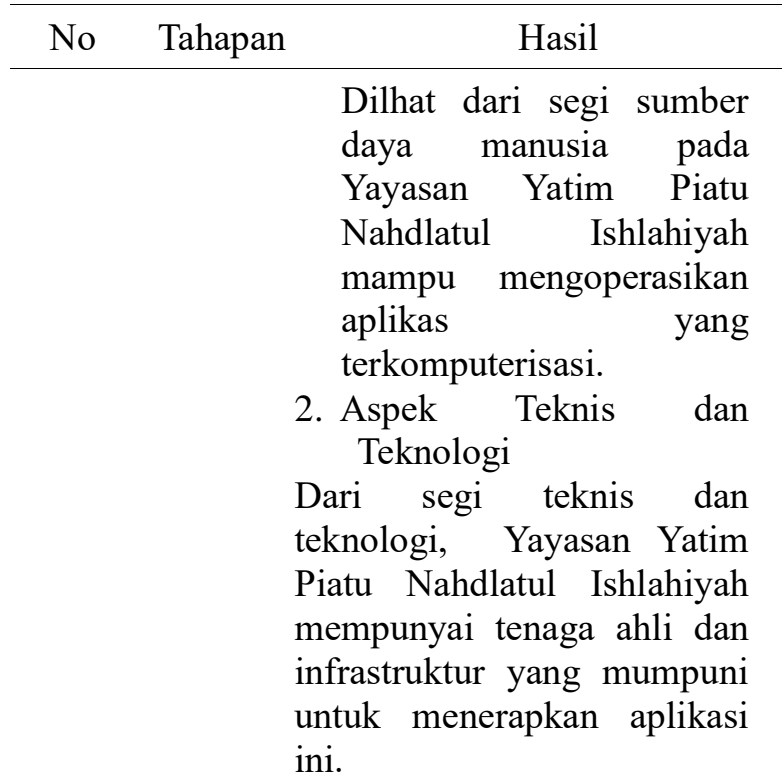

4. Timproyek Anggota tim proyek yang terlibat dalam membangun aplikasi ini terdiri dari :

1. Satu orang analisis yang mempunyai tugas menganalsisis setiap permasalahan yang ada

2. Satu orang programmer yang mempunyai tugas mengimplementasikan hasil dari analisis ke kode program

5. Peluncuran Aplikasi ini akan proyek diluncurkan pada bulan januari 2018 b. Tahapan prosedur berjalan dalam penerimaan dana donasi di yayasan yatim piatu Nahdlatul Ishlahiyah. Berikut ini adalah sistem berjalan dalam penerimaan dana donasi yaitu sebagai berikut :

1) Donatur mengunjungi yayasan yatim piatu Nahdlatul Ishlahiyah

2) Donatur mengisi buku tamu lalu menyerahkan donasi

3) Donatur menerima tanda terima donasi dari bendahara

c. Struktur organisasi yang ada di Yayasan Yatim Piatu Nahdlatul Ishlahiyah beserta tugas-tugasnya.

2. Analisis Sistem

a) Actor Discription

Untuk aktor terdiri dari tiga, yaitu Donatur, bendahara dan ketua.

b) Use Case Diagram

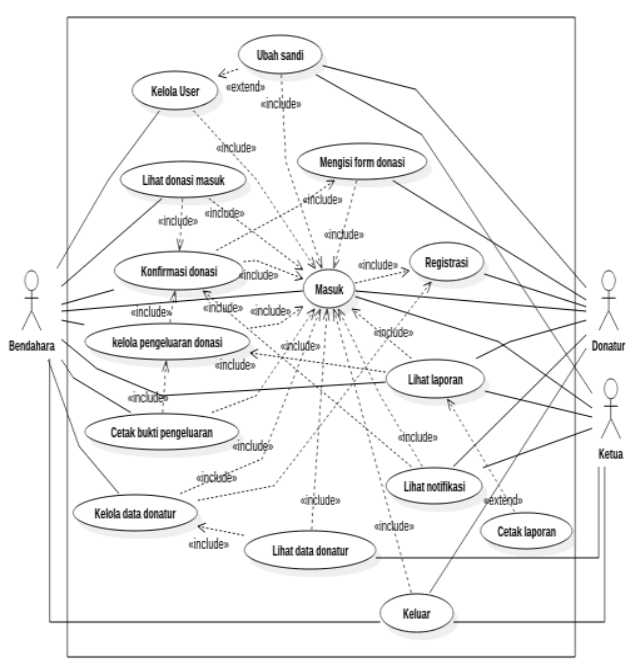

Gambar 2, Use Case Diagram

c) Skenario use case

Skenario Use Case terdiri dari registari, masuk, mengisi form registrasi, ubah sandi, lihat donasi masuk, kelola data user, kelola data donator, konfirmasi donasi, kelola pengeluaran donasi, cetak laporan donasi, lihat notifikasi, lihat laporan donasi,cetak bukti pengeluaran, keluar.

d) Class Diagram

Class diagram terdiri dari 7 class yaitu class donasi, class basisdata, class 
pengeluaran, class user, class pesan, class formulir dan class donatur

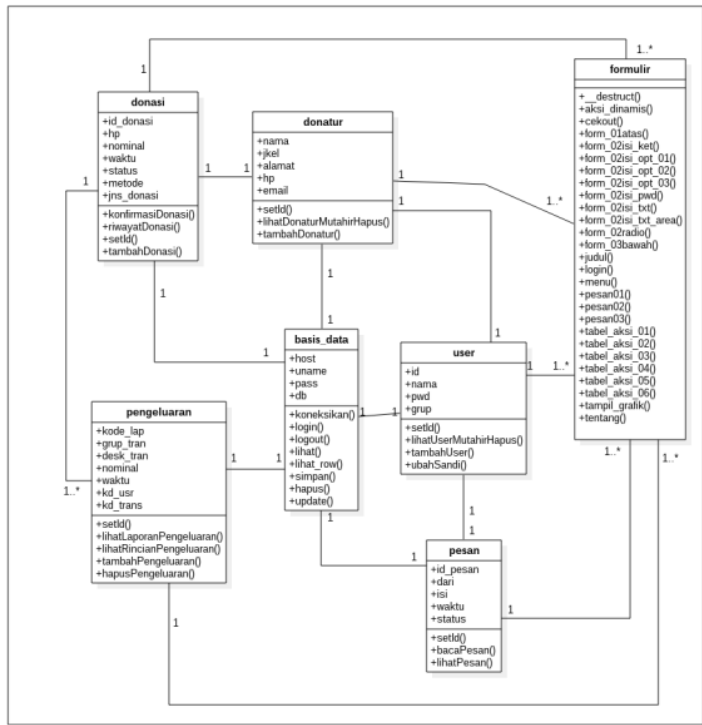

Gambar 3 Class diagram

e) Sequence diagram

Sequence diagram terdiri dari dari registari, masuk, mengisi form registrasi, ubah sandi, lihat donasi masuk, kelola data user, kelola data donator, konfirmasi donasi, kelola pengeluaran donasi, cetak laporan donasi, lihat notifikasi, lihat laporan donasi,cetak bukti pengeluaran, keluar.

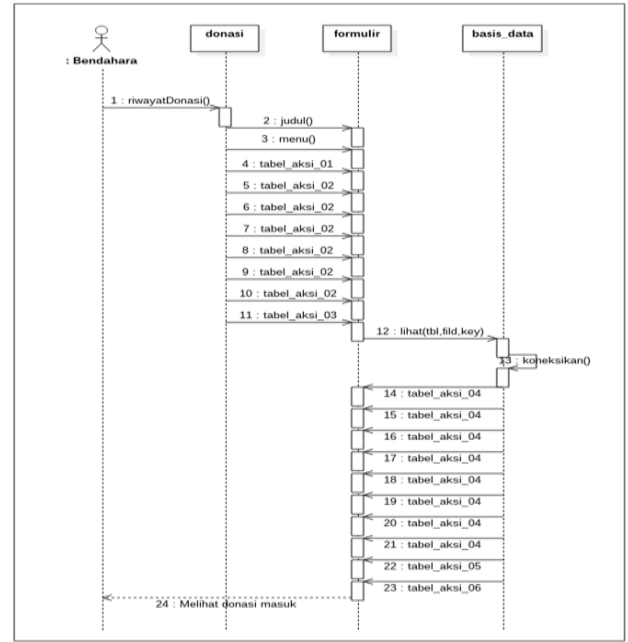

Gambar 4 Sequence diagram lihat donasi masuk f) Activity diagram

Activity diagram terdiri dari registari, masuk, mengisi form registrasi, ubah sandi, lihat donasi masuk, kelola data user, kelola data donator, konfirmasi donasi, kelola pengeluaran donasi, cetak laporan donasi, lihat notifikasi, lihat laporan donasi,cetak bukti pengeluaran, keluar.

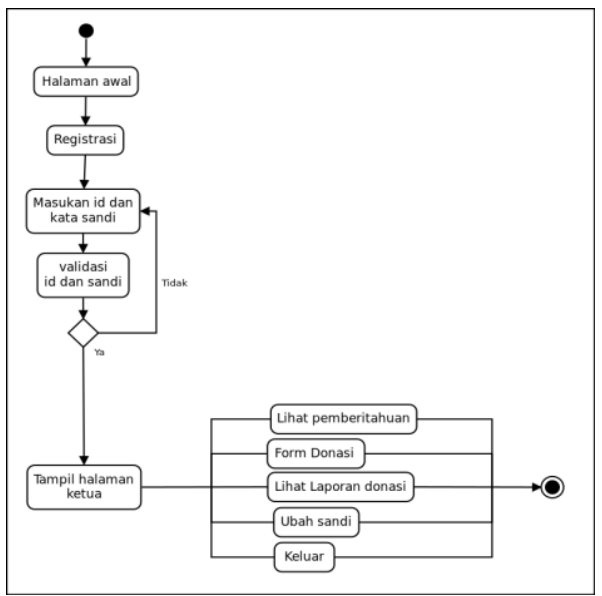

Gambar 5 Activity diagram kelola data donator

\section{Hasil Design Phase}

1. Desain Proses

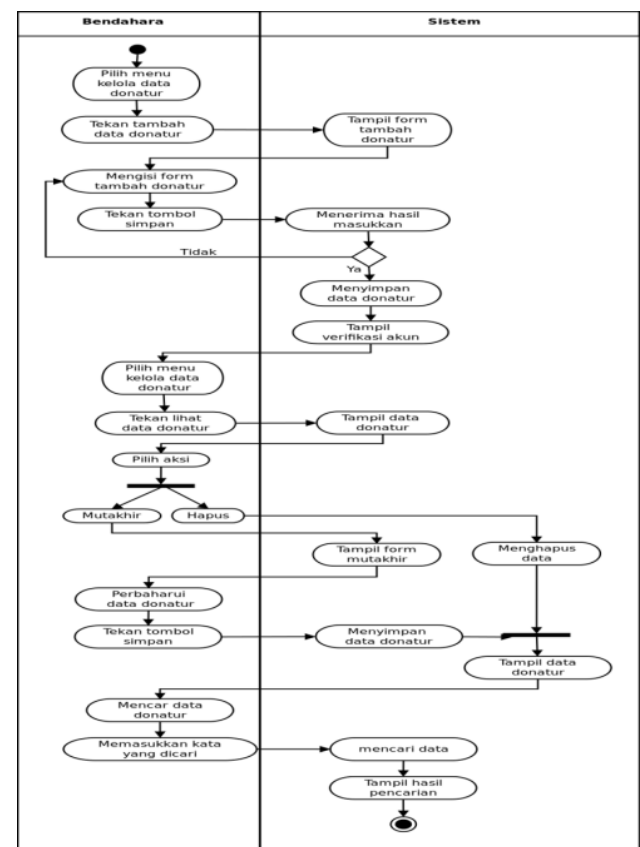

Gambar 6 Desain Proses 


\section{Desain Database}

Adapun database yang dibuat adalah database dbdonasi yang terdiri dari 5 tabel yaitu tabel donasi, tabel donator, tabel pengeluaran, tabel pesan dan tabel user.

\section{Desain Antarmuka}

Desain antarmuka yang dibuat ada desain antarmuka masukan (input) dan desain antarmuka keluaran (output). Desain antarmuka masukan terdiri dari form masuk,form pengeluaran donasi, form tambah data donator, form tambah data user, form ubah sandi form registrasi, form donasi. Berikut ini contoh masukan form donasi

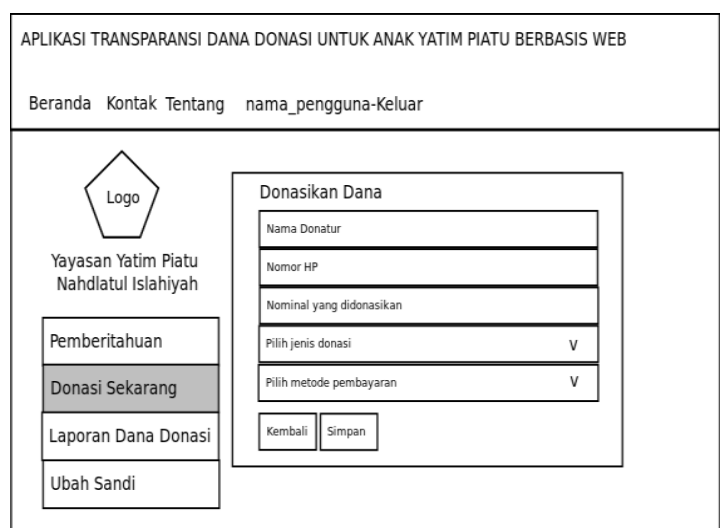

Gambar 7 Desain antarmuka masukan form donasi

Desain antarmuka keluaran terdiri dari data pengeluaran donasi dan laporan donasi,

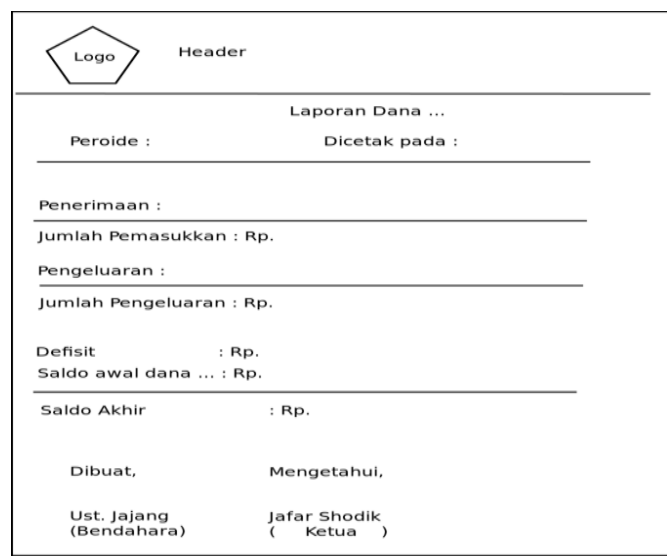

Gambar 8 Desain antarmuka keluaran laporan donasi

\subsection{Implementation Phase}

Pada fase ini dilakukan tiga kegiatan yaitu :

1. Spesifikasi kebutuhan sistem yang terdiri dari spesifikasi kebutuhan software dan hardware.

2. Instalasi Perangkat lunak yang terdiri dari Instalasi Apache2 HTTP Server, Instalasi $M y S Q L$ dan Instalasi Aplikasi Transparansi Dana Donasi Berbasis Web.

3. Pelatihan prosedural penggunaan sistem untuk bendahara dan ketua.

Berikut ini salah satu contoh menu halaman utama aplikasi :

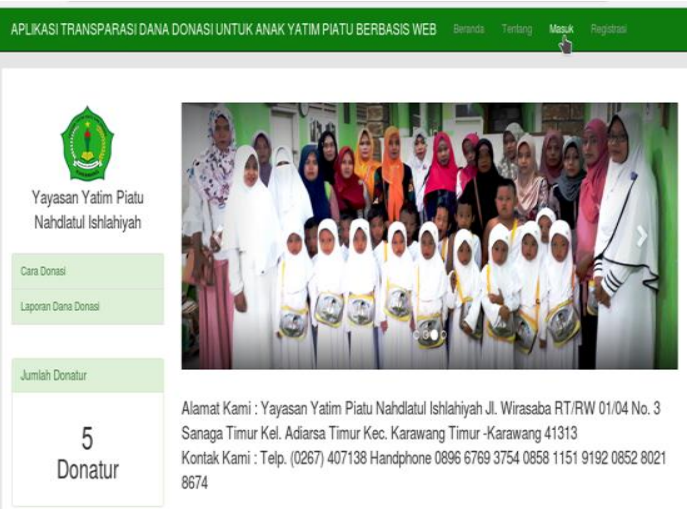

Gambar 9 Halaman menu utama

4. Pengujian sistem meliputi pengujian white box dan black box

Berikut ini tabel hasil pengujian :

Tabel 2 Pengujian Black Box

\begin{tabular}{clll}
\hline $\begin{array}{c}\text { N } \\
\text { o }\end{array}$ & $\begin{array}{l}\text { Nama } \\
\text { Fungsi }\end{array}$ & Kriteria & $\begin{array}{l}\text { Hasil } \\
\text { Pengujia } \\
\text { n }\end{array}$ \\
\hline 1 & Fungsi & Correctness & OK \\
& Masuk & , Reliability, & \\
& sistem & Efficiency, & \\
& & Integrity, \\
& & Usability, \\
& & Portability, \\
& & & \\
& Fungsi & Reusability \\
& konfirmasi & Correctness & OK \\
& donasi & Reliability, \\
& & Efficiency, \\
& & Integrity, \\
& & Usability, \\
& & Portability, &
\end{tabular}


Reusability

3 Fungsi lihat Correctness donasi , Reliability, masuk Efficiency,

Integrity,

Usability,

Portability,

Reusability

4 Fungsi Correctness

kelola , Reliability,

pengeluara Efficiency,

n donasi Integrity,

Usability,

Portability,

Reusability

5 Fungsi Correctness

kelola data , Reliability,

donatur Efficiency,

Integrity,

Usability,

Portability,

Reusability

6 Fungsi lihat Correctness laporan , Reliability, dana donasi Efficiency,

Integrity,

Usability,

Portability,

Reusability

7 Fungsi Correctness

cetak , Reliability,

laporan Efficiency,

donasi Integrity,

Usability,

Portability,

Reusability

8 Fungsi Correctness

kelola data , Reliability,

user Efficiency,

Integrity,

Usability,

Portability,

Reusability

9 Fungsi ubah Correctness sandi , Reliability,

Efficiency,

Integrity,

Usability,

Portability,

Reusability
$\mathrm{OK}$

10

Fungsi

Correctness

$\mathrm{OK}$

Efficiency,

Integrity,

Usability,

Portability,

Reusability

OK

11 Fungsi lihat Correctness

notifikasi , Reliability,

Efficiency,

Integrity,

Usability,

Portability,

Reusability

$\mathrm{OK}$

12 Fungsi

Correctness

mengisi

, Reliability,

form donasi Efficiency,

Integrity,

Usability,

Portability,

Reusability

$\mathrm{OK}$

\section{KESIMPULAN DAN SARAN}

\section{Kesimpulan}

Berdasarkan penelitian yang sudah dilakukan maka dapat ditarik kesimpulan :

1. Dengan memanfaatkan teknologi internet

OK yang saat ini banyak digunakan dan mudah diakses dimanapun dan kapanpun oleh donatur atau masyarakat luas sehingga data pemasukkan dan pengeluaran donasi pada yayasan yatim piatu Nahdlatul Ishlahiyah dapat dilihat secara online. Pelaporan donasi yang disampaikan secara transparan dapat meningkatkan kepercayaan para donatur.

2. Penggunaan metode pengembangan sistem SDLC waterfall dapat diterapkan dalam membangun aplikasi ini

\section{Saran}

$\mathrm{OK}$

Adapun rekomendasi beberapa hal mengenai aplikasi yang telah diimplementasikan sehingga dapat dikembangkan lebih baik yaitu dengan:

1. Aplikasi ini dapat dikembangkan menjadi berbasis mobile (android) dengan tampilan yang lebih menarik. 
2. Laporan keuangan pada aplikasi ini dapat dikembangankan kembali secara accounting sehingga pelaporan keuangan yang disajikan lebih lengkap.

\section{DAFTAR PUSTAKA}

Welim, Yohannes Yahya dan Anugrah Rahmat Sakti. 2016. Rancang Bangun Sistem Informasi Administrasi Pengelolaan Dana Masjid Pada Yayasan AlMuhajiriin, Tangerang, ISSN: 22524983. Vol 7 No 1.

Fitriana, Saghifa dan Ridho Wijayanto. 2014. Perancangan Sistem Informasi Panti Asuhan Sebagai Media Untuk Mempermudah Ranting Dalam Merekomendasikan Anak Panti (Studi Kasus : Panti Asuhan Muhammadiyah Cabang Purwokerto), ISSN : 2338-8161. Vol. II No. 2.

Supriyanta dan Eunike Nova Dwi Floren Rindani Nussy. 2016. Perancangan Website Sebagai Media Informasi Panti Asuhan Batu Penjuru Kulon Progo, ISSN : 1979-9330 (Print) - 2088-0154 (Online). Volume 8 No 2.

Srijatun. 2016. Implementasi Model Pendidikan Pondok Pesantren Di Panti Asuhan Puteri Aisyiyah Slawi Kabupaten Tegal, Volume. 10, Nomor 1. Asuhan Puteri Aisyiyah Slawi Kabupaten Tegal, Volume. 10, Nomor 1.

Wulandari, Sri Hariani Eko. 2017.Aplikasi Transparansi Sumbangan Masyarakat Berbasis Web. Surabaya: Institut Bisni dan Informatika Stikom Surabaya. ISSN: 2460 - 6839. Volume 2 Nomor 1.

Satzinger, Jhon W., Jackson, Robert B., Burd, Stephen D. 2010. System Analysis and Design In a Changing World, Fifth Edition, Thomson Course Techonlogy USA.

Harahap, N.S. 2012. Pemrograman Aplikasi Mobile Smartphone dan Tablet PC Berbasis Android. Bandung : Informatika.

Dewantry, Zenita Wahyu, Sari Dewi Budiwati, Muhammad Barja Sanjaya. 2015.
Aplikasi Pengelolaan Dana Donasi Untuk Penderita Kanker (Studi Kasus : Yayasan Kanker Indonesia), Bandung: Universitas Telkom. ISSN : 24425826. Vol.1 No.3

Kamus Besar Bahasa Indonesia. 2016. Transparansi (Online). Website: http://kbbi.kemdikbud.go.id (diakses tanggal 19 Oktober 2017).

Kamus Besar Bahasa Indonesia. 2016. Anak Yatim Piatu (Online). Website: http://kbbi.kemdikbud.go.id (diakses tanggal 19 Oktober 2017). 